\title{
Epidemiology of Blackberry yellow vein associated virus
}

Bindu Poudel, Department of Plant Pathology, Division of Agriculture, University of Arkansas System, Fayetteville 72701; William M. Wintermantel and Arturo A. Cortez, United States Department of Agriculture-Agricultural Research Service, Salinas, CA 93905; and Thien Ho, Archana Khadgi, and Ioannis E. Tzanetakis, Department of Plant Pathology, Division of Agriculture, University of Arkansas System

\begin{abstract}
Poudel, B., Wintermantel, W. M., Cortez, A. A., Ho, T., Khadgi, A., and Tzanetakis, I. E. 2013. Epidemiology of Blackberry yellow vein associated virus. Plant Dis. 97:1352-1357.

Blackberry yellow vein disease is one of the most important diseases of blackberry in the United States. Several viruses are found associated with the symptomology but Blackberry yellow vein associated virus (BYVaV) appears to be the most prevalent of all, leading to the need for a better understanding of its epidemiology. Efficient detection protocols were developed using end-point and quantitative reverse-tran-

formed on wild and cultivated blackberry to assess the geographical distribution of the virus. Two whitefly species, Trialeurodes abutilonea and $T$. vaporariorum, were identified as vectors and 25 plant species were tested as potential BYVaV hosts. The information obtained in this study can be used at multiple levels to better understand and control blackberry yellow vein disease.
\end{abstract} scription polymerase chain reaction. A multi-state survey was per-
Over the past few decades, blackberry cultivation has flourished, accompanied by an increase in consumer demand and the release of new cultivars suitable for the fresh market $(1,2)$. A survey conducted in 2005 reported a worldwide increase of $45 \%$ in acreage devoted to blackberry production (9). However, expanded production has also led to the emergence of several pests and pathogens. Blackberry yellow vein disease (BYVD) is the most important disease of blackberry in the southeastern United States (4). It was first observed in 2000 in the Carolinas and has since become a serious concern for all blackberry production in the southeastern United States $(3,17)$. Symptoms include vein yellowing of primocane leaves, oak-leaf patterns, irregular chlorosis, and line patterns $(10,12$; Fig. 1). Floricanes can be severely affected and cane dieback has been observed during the fruiting season. The principal effect of BYVD is reduced yield that leads to replanting every 5 to 7 years, where fields used to remain productive for more than 20 years, with every replanting costing at least $\$ 15,000 /$ ha (4). As an example, in one field, only a few 2-year-old 'Chickasaw' blackberry plants showed symptoms in 2003 and, within 2 years, BYVD spread throughout the field, leading to total yield loss (11).

The disease was initially mistaken for Tobacco ringspot virus (TRSV) infection; however, nematode and graft experiments proved that TRSV is asymptomatic in many blackberry cultivars R. C. Gergerich, unpublished). The presence of TRSV in only a small subset of BYVD plants led to the discovery of a new crinivirus, subsequently named Blackberry yellow vein associated virus (BYVaV) (3). Although all symptomatic plants in the Martin et al. study (3) were infected with BYVaV, further screening indicated that $\mathrm{BYVaV}$ is latent in single infections (11). It is now clear that BYVD is caused by virus complexes and several other viruses

\section{Corresponding author: I. E. Tzanetakis, E-mail: itzaneta@uark.edu}

Current address of B. Poudel: Entomology, Soils, and Plant Sciences, Clemson University, Clemson, SC 29634.

*The $e$-Xtra logo stands for "electronic extra" and indicates that supplementary text is available online and that Figures 1 and 2 appear in color online.

Accepted for publication 29 March 2013.

http://dx.doi.org/10.1094/PDIS-01-13-0018-RE

(C) 2013 The American Phytopathological Society were discovered in BYVD-infected plants, including Blackberry virus $Y$ (13), Impatiens necrotic spot virus (15), Rubus virus S (7), Blackberry virus E (8), and Blackberry chlorotic ringspot virus (5), among others.

BYVaV is a member of the genus Crinivirus, family Closteroviridae (18). Criniviruses have emerged to cause new diseases around the world because of the expanding range of their whitefly vectors and trade practices involving movement of plant material (19). This has resulted in rapid dissemination and exposure of criniviruses to new plant species in previously unaffected areas. The recent expansion of blackberry production has likely had a significant impact on BYVD incidence. Successful management of BYVD requires knowledge of pathogen epidemiology, including alternative hosts and vector transmission. This communication aims to bridge the knowledge gap concerning the most important blackberry virus in the Southeastern United States, providing detailed information on efficient detection, incidence, host range, and transmission of BYVaV.

\section{Materials and Methods}

Reverse-transcription polymerase chain reaction detection. Nucleic acids were isolated from the area surrounding the primary vein of young, fully matured blackberry leaves. Briefly, leaf tissue $(50 \mathrm{mg})$ was ground in $1 \mathrm{ml}$ of extraction buffer $(200 \mathrm{mM}$ Tris- $\mathrm{HCl}$ [pH 8.5], $300 \mathrm{mM}$ lithium chloride, $1.5 \%$ lithium dodecylsulphate, $10 \mathrm{mM}$ ethylenediaminetetra-acetic acid [EDTA], $1 \%$ sodium deoxycholate, $1 \% \mathrm{NP}-40$, and $1 \% 14 \mathrm{M} \beta$-mercaptoethanol solution [vol/vol] added just before use). An equal amount of $5.8 \mathrm{M}$ potassium acetate $(3.8 \mathrm{M}$ potassium and $5.8 \mathrm{M}$ acetate) was added to the mixture $(600 \mu \mathrm{l})$ and centrifuged at $16,000 \times g$ for $10 \mathrm{~min}$. The supernatant $(750 \mu \mathrm{l})$ was mixed with an equal volume of $100 \%$ isopropanol and chilled at $-20^{\circ} \mathrm{C}$ for at least $30 \mathrm{~min}$. The mixture was then centrifuged for $20 \mathrm{~min}$ and the resulting pellet was resuspended in $500 \mu \mathrm{l}$ of wash buffer $(10 \mathrm{mM}$ Tris- $\mathrm{HCl}$ [pH 7.5], $0.5 \mathrm{mM}$ EDTA, $50 \mathrm{mM} \mathrm{NaCl}$, and $50 \%$ ethanol) and $20 \mu \mathrm{l}$ of silica per glass of milk was added. The mixture was pulse centrifuged for $10 \mathrm{~s}$ at $9,400 \times \mathrm{g}$ and washed twice to eliminate inhibitors. After the final wash, the mixture was centrifuged for $2 \mathrm{~min}$ at $16,000 \times \mathrm{g}$ and the pellet was dried in a speedvac (Thermo Fisher Scientific). The pellet was resuspended in $150 \mu \mathrm{l}$ Tris-EDTA $(10 \mathrm{mM}$ Tris- $\mathrm{HCl}$ and $1 \mathrm{mM}$ EDTA, pH 8.0) and centrifuged for $2 \mathrm{~min}$ at $13,500 \times \mathrm{g}$. Then, $100 \mu \mathrm{l}$ was collected and an aliquot was used in downstream reactions.

After obtaining sequence information from 34 virus isolates (6), primers were developed to the most conserved region of the virus 
genome. Primers BYVaVF/BYVaVR (Table 1) provided the most reliable results in the pilot studies. Purified nucleic acids $(2.5 \mu \mathrm{l})$ were used in a $25-\mu \mathrm{l}$ reverse-transcription (RT) reaction as previously described (6) and cDNA template was used as $2.5 \%$ of the 25- $\mu$ l PCR reaction that consisted of $2.5 \mu \mathrm{l}$ of $10 \times$ PCR reaction buffer (GeneScript), $0.4 \mu \mathrm{M}$ each primer, $0.2 \mathrm{mM}$ dNTPs, and 0.25 units of Taq Polymerase (GeneScript). RNA quality of nucleic acid extracts was verified by inclusion of an internal host RNA polymerase chain reaction (PCR) control, as previously described (16). The PCR program for BYVaV detection on a C1000 Thermal Cycler (Bio-Rad) consisted of initial denaturation at $94^{\circ} \mathrm{C}$ for $1 \mathrm{~min}$; followed by denaturation at $94^{\circ} \mathrm{C}$ for $15 \mathrm{~s}$, annealing at $55^{\circ} \mathrm{C}$ for 15 $\mathrm{s}$, and extension at $72^{\circ} \mathrm{C}$ for $30 \mathrm{~s}$, repeated for 30 cycles; and final extension of $72^{\circ} \mathrm{C}$ for $10 \mathrm{~min}$. The samples were visualized in a $2 \%$ Tris-borate-EDTA agarose gel stained with GelRed (Biotium). More than 10 amplicons were sequenced directly and were all found to be virus specific, validating the quality of the protocol.

Quantitative RT-PCR detection. Preparation of RNA and RT for quantitative detection was as described above, except that total nucleic acids were further digested with 2 units of DNase in corresponding buffer (RQ1 DNase reaction buffer; Promega Corp.), incubated at $37^{\circ} \mathrm{C}$ for $1 \mathrm{~h}$. The reaction was terminated with the addition of $20 \mathrm{mM}$ EGTA, pH 8.0 (Promega Corp.), at $65^{\circ} \mathrm{C}$ for 10 min. RNA concentration was normalized to $100 \mathrm{ng} / \mu \mathrm{l}$ in water.

All regions of the BYVaV genome were evaluated as targets for the quantitative PCR (qPCR) probe-primer design. Polymorphism among sequences was significant and no homologous nucleotide stretches could be found suitable for designing TaqMan assays using default qPCR software parameters. In order to develop assays, degenerate oligonucleotide primers were evaluated. BYVaV sequences were evaluated using PrimerQuest (Integrated DNA Technologies [IDT]) to generate probe sequences. The output was processed using a BASIC macro (Supplementary Text) that sorted probes based on their starting positions along the genome. The probes were aligned against BYVaV sequences (GenBank accessions AY776334-5 and JQ756161 to JQ562967) using ClustalW (14). Probes and primers were manually designed with the assistance of Oligo Analyzer tool 3.1 (IDT) evaluating physical
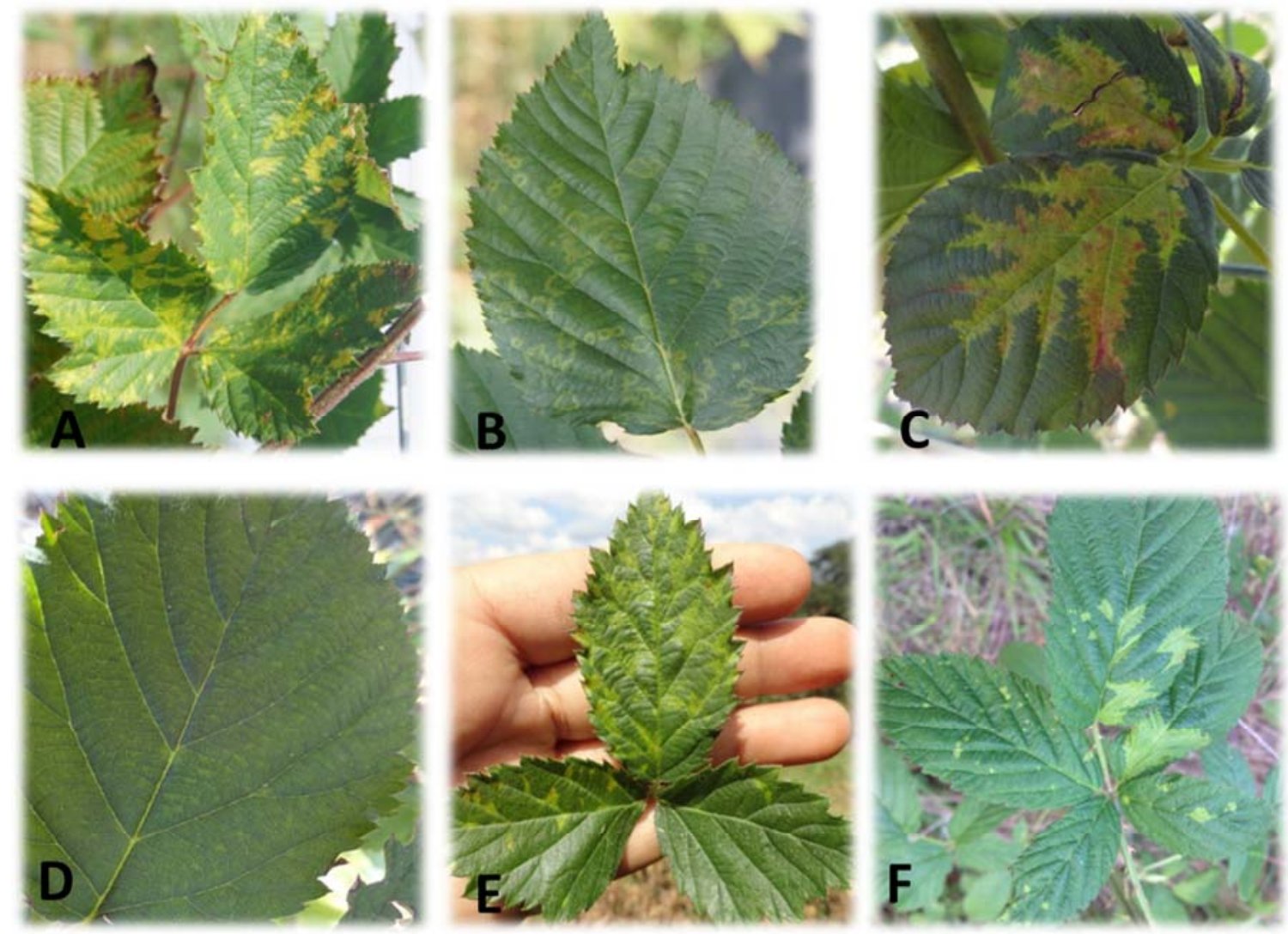

Fig. 1. Blackberry infected with Blackberry yellow vein associated virus and showing symptoms commonly associated with blackberry yellow vein disease (BYVD). A, Chlorosis; B, ringspots; $\mathbf{C}$, oak leaf pattern; $\mathbf{D}$, mild chlorotic spots; $E$, mosaic; and $\mathbf{F}$, vein banding and chlorosis.

Table 1. Primers used in epidemiological studies of Blackberry yellow vein associated virus

\begin{tabular}{ll}
\hline Primer names $^{\mathrm{a}}$ & \multicolumn{1}{c}{ Sequences } \\
\hline Crini RT primer $^{\mathrm{b}}$ & \multicolumn{1}{c}{ TTTTYGAGWTTTTAWAATACA } \\
RdRp 450Fc & CAGGATTGATAAGTGGTTGGAGAC \\
RdRp 450R & CAAGAACATCGGCGAGTAAAAC \\
BYVaVF & TTGAAAGGAAACTTCACGGA \\
BYVaVR & TAAGTTCATACGTTTCCTGCG \\
BYVV Pol mid F & CTTCAGCAGAGAGATTGGTG \\
BYVV Pol mid R & CCAAGAACATCGGCGAGT \\
BYVaV2.867 probe & 6-FAM/TTGAAAAGA/Zen/TGGGTYGGHGTGGACA/IABkFQ \\
BYVaV2.867 F & ATAGAAGCGAGGTTAARACCTG \\
BYVaV2.867 R & CACRTYGTTACCTCTAAGCTCG \\
\hline
\end{tabular}

\footnotetext{
${ }^{\mathrm{a}} \mathrm{F}=$ forward and $\mathrm{R}=$ reverse

${ }^{\mathrm{b}}$ Degenerate primer for criniviruses, used in reverse transcription.

${ }^{\mathrm{c}}$ Detection primers used in whitefly transmission.
} 
properties. Nondegenerate probes were preferred over nondegenerate primers when possible, and nondegenerate primers were preferred over amplicon length.

qPCR assays were performed with $2.5 \%$ cDNA in $20-\mu$ reactions using the $2 \times$ Universal PCR Master Mix (Applied Biosystems) and 10x PrimeTime qPCR Assays probe-primer mix (IDT) with probe and primer concentrations set at 0.25 and $0.5 \mu \mathrm{M}$, respectively.

Thermocycler conditions on a CFX96 Real-Time PCR System (Bio-Rad) consisted of $50^{\circ} \mathrm{C}$ for $2 \mathrm{~min}$ and $95^{\circ} \mathrm{C}$ for $10 \mathrm{~min}$, followed by 40 cycles of $95^{\circ} \mathrm{C}$ for $15 \mathrm{~s}$ and $60^{\circ} \mathrm{C}$ for $1 \mathrm{~min}$. Controls were included in each run accordingly. End-point PCRs were conducted using the qPCR primers (Table 1) to obtain amplicons for the development of standard curves. Briefly, the products were diluted $1,000 \times$ in water and $2.5 \mu \mathrm{l}$ of the diluted DNA was added per tube in PCR reactions, as described above. DNA bands of expected amplicon size (131 bp) were cloned, transformed into Escherichia coli, and sequenced as previously described (6). DNA concentrations were measured on a NanoDrop 1000 (Thermo Scientific) and 10-fold serial dilutions were prepared. Standard curves were constructed from three replicates of the plasmid dilution.

Incidence. Samples collected during a survey conducted between 2008 and 2011, including commercially grown and wild blackberry from Arkansas, California, Florida, Georgia, Illinois, Mississippi, North Carolina, South Carolina, and West Virginia (Table 2), were assessed for BYVaV incidence using the universal RT-PCR detection protocol described above.

Natural host range. Twenty-five plant species collected in areas of high BYVaV incidence were tested as potential alternate hosts of the virus (Table 3). Plant species were collected from areas with high BYVaV incidence with at least 16 plants/species tested. Plants were sampled from April to September so as to identify early, mid-, and late-season host species. Nucleic acids were extracted on the day of collection to ensure quality, followed by RT-PCR analysis as described above.

Transmission. BYVaV belongs to Crinivirus group 1 (21). All members of the group are transmitted by whiteflies in the genus Trialeurodes. For this reason, banded-winged (Trialeurodes abutilonea) and greenhouse (T. vaporariorum) whiteflies were tested for their ability to transmit the virus. Both $T$. vaporariorum and $T$. abutilonea were reared on Physalis wrightii (groundcherry) and Malva parviflora (cheeseweed mallow). Whitefly colonies were maintained virus free in insect-proof cages at temperatures of 26 to $32^{\circ} \mathrm{C}$. Source plants for all transmission studies were blackberry 'Natchez', tested for all known blackberry viruses and found infected only with BYVaV, as concluded after doubled-stranded

Table 2. Geographical incidence of Blackberry yellow vein associated virus in plants showing virus-like symptoms

\begin{tabular}{llccc}
\hline & & & Positive/total $^{\mathbf{a}}$ \\
\cline { 3 - 5 } Year & \multicolumn{1}{c}{ State } & Cultivated blackberry & Wild blackberry $^{\text {Total }}$ \\
\hline 2008 & North Carolina & $10 / 11$ & N/A & $10 / 11$ \\
2008 & Arkansas & $18 / 24$ & $6 / 8$ & $24 / 32$ \\
2008 & Georgia & $3 / 3$ & N/A & $3 / 3$ \\
2009 & North Carolin & $25 / 37$ & N/A & $25 / 37$ \\
2009 & South Carolina & $19 / 24$ & N/A & $19 / 24$ \\
2009 & Arkansas & $15 / 23$ & N/A & $15 / 23$ \\
2009 & California & $3 / 6$ & N/A & $3 / 6$ \\
2009 & Mississippi & $2 / 2$ & N/A & $2 / 2$ \\
2009 & Oklahoma & $9 / 10$ & N/A & $9 / 10$ \\
2010 & Arkansas & N/A & $7 / 45$ & $21 / 45$ \\
2010 & West Virginia & N/A & $6 / 9$ & $7 / 9$ \\
2010 & Illinois & N/A & N/A & $6 / 6$ \\
2011 & Georgia & $0 / 13$ & N/A & $0 / 13$ \\
2011 & Florida & $1 / 13$ & $40 / 68$ & $1 / 13$ \\
Total & . & $105 / 166$ & & $145 / 234$ \\
\hline
\end{tabular}

a N/A = not available.

Table 3. Plant species tested as potential alternative hosts for Blackberry yellow vein associated virus

\begin{tabular}{|c|c|c|c|}
\hline Plant species & Scientific name & Family & Number of plants tested \\
\hline Garden vetch & Vicia sativa & Fabaceae & 16 \\
\hline Virginia creeper & Parthenocissus quinquefolia & Vitaceae & 16 \\
\hline Red clover & Trifolium pretense & Fabaceae & 16 \\
\hline Wild garlic & Allium vineale & Amaryllidaceae & 16 \\
\hline Creeping woodsorrel & Oxalis corniculata & Oxalidaceae & 16 \\
\hline Carolina geranium & Geranium carolinianum & Geraniaceae & 16 \\
\hline Curly dock & Rumex crispus & Polygonaceae & 16 \\
\hline Dandelion & Taraxacum officinale & Asteraceae & 16 \\
\hline Tall fescue & Festuca arundinacea & Poaceae & 16 \\
\hline Wild wheat & Avena fatua & Poaceae & 16 \\
\hline Grapes & Vitis vinifera & Vitaceae & 16 \\
\hline Peach & Prunus persica & Rosaceae & 16 \\
\hline Blueberry & Vaccinium spp. & Ericaceae & 16 \\
\hline Shepherd's purse & Capsella bursa-pastoris & Brassicaceae & 16 \\
\hline Nutsedge & Cyperus spp. & Cyperaceae & 16 \\
\hline Horsenettle & Solanum carolinense & Solanaceae & 16 \\
\hline Common ragweed & Ambrosia artemisiifolia & Asteraceae & 16 \\
\hline Tree of heaven & Ailanthus altissima & Simaroubaceae & 16 \\
\hline Apple & Malus spp. & Rosaceae & 200 \\
\hline Rose & Rosa multiflora & Rosaceae & 40 \\
\hline Carpetweed & Mollugo verticillata & Molluginaceae & 16 \\
\hline Amaranthus & Amaranthus spp. & Amaranthaceae & 16 \\
\hline Poor joe & Diodia teres & Rubiaceae & 16 \\
\hline Ground cherry & Physalis spp. & Solanaceae & 16 \\
\hline Sorghum & Sorghum spp. & Poaceae & 16 \\
\hline
\end{tabular}


RNA and RT-PCR analysis. In independent experiments, whiteflies of each species were allowed acquisition access periods (AAPs) of 18 to $24 \mathrm{~h}$ on source plants followed by transmission in clip cages, as previously described (19). Following the AAP, whiteflies were vacuum collected and placed in clip cages, with 50 individual whiteflies per cage. Clip cages were attached to the underside of leaves and whiteflies were given an inoculation access period (IAP) of $48 \mathrm{~h}$, after which cages were removed. One month following transmissions, total nucleic acids were extracted as described above. RT was performed using MMLV reverse transcriptase (Promega Corp.) according to manufacturer's recommendations, with $0.5 \mu \mathrm{M}$ reverse gene-specific primer (Crini RT primer; Table 1), $1.5 \mu$ of total nucleic acid template, and incubation at $42^{\circ} \mathrm{C}$ for $1.5 \mathrm{~h}$. PCR was performed as described above but with Go-Taq polymerase (Promega Corp.) and primers designed for open reading frame $1 \mathrm{~b}$ (Table 1$)$.

Rose was evaluated specifically as a potential reservoir host for BYVaV because wild blackberry and rose plants coexist in areas of high BYVD incidence in the southeastern United States. Twigs of BYVaV singly infected blackberry were grafted on to 1-month-old Rosa multiflora seedlings. Ten rose seedlings were V-grafted with blackberry, kept in a moist chamber for 14 days, and grown for 4 weeks in a greenhouse before being tested for the presence of BYVaV by RT-PCR. Additionally, a limited number of rose seedlings were evaluated in transmission experiments to determine whether BYVaV could be transmitted to rose by vector whiteflies. Virus acquisition was conducted as described above for transmission to blackberry, with exclusively $T$. abutilonea whiteflies feeding for $24 \mathrm{~h}$ on young, BYVaV-infected blackberry source plants. Inoculation of rose involved free feeding of viruliferous $T$. abutilonea in large sealed cages with a minimum of 50 whiteflies/plant for $48 \mathrm{~h}$. Inoculation appeared to be effective because many whiteflies remained alive at the end of the feeding period. Following transmission, plants were sprayed with resmethrin and soil was treated with Marathon (Imidacloprid) to eliminate whiteflies.

\section{Results}

Detection. More than 20 different sets of primers were developed and tested for their specificity for amplifying virus-specific sequences (data not shown). BYVaVF and BYVaVR (Table 1) were the most efficient primers that did not produce any amplicons in the negative controls (Fig. 2). The qPCR assays were designed to target four regions of the BYVaV genome (6). Several assays were designed and tested (data not shown). Based on the consistency of their quantification cycle $(\mathrm{Cq})$ values and intensity or noise of fluorescence signals, the BYVaV2.867 primer set (Table 1) was selected for further evaluation. Properties of the BYVaV2.867 curve, repeated more than five times, were consistently within the recommended range of qPCR efficiency ( 95 to $105 \%)$, correlation coefficient $(>0.990)$, slope $(-3.3 \pm 10 \%)$, and y-intercept (close to 40) (Fig. 2).

The BYVaVF/BYVaVR primer set (Table 1) was employed to amplify the virus from the same cDNA templates used in the qPCR assays and compare the techniques. The cDNA samples were serially diluted eightfold, corresponding to a three-PCR-cycle difference. Quantitative and end-point PCR could detect BYVaV at 1/4,096 and 1/64 dilutions, respectively (Fig. 2).

Incidence. In total, 234 BYVD samples of cultivated and wild blackberry plants were collected from nine states (Table 3) and tested for the presence of BYVaV by RT-PCR. The virus was present in all of the states, including Illinois and West Virginia, where it had not been documented before. The virus was detected in approximately 63 and $58 \%$ of cultivated and wild blackberry samples respectively, overall.

Natural host range. BYVaV was not detected in any of the 25 plant species tested as potential alternative hosts. However, one grafted rose tested positive for the virus after RT-PCR, with confirmation by sequencing of the amplicon. Detection was repeated three times to eliminate the possibility of contamination. The infected rose plant has been symptomless for two seasons, even after pruning and overwintering. Attempts to transmit BYVaV to rose using viruliferous $T$. abutilonea were not successful. Six plants were inoculated over two experiments; however, none developed infection with BYVaV.

Transmission. Both T. abutilonea and T. vaporariorum were able to transmit BYVaV from infected Natchez blackberry to healthy Natchez blackberry seedlings. In all, 12 of 25 plants used

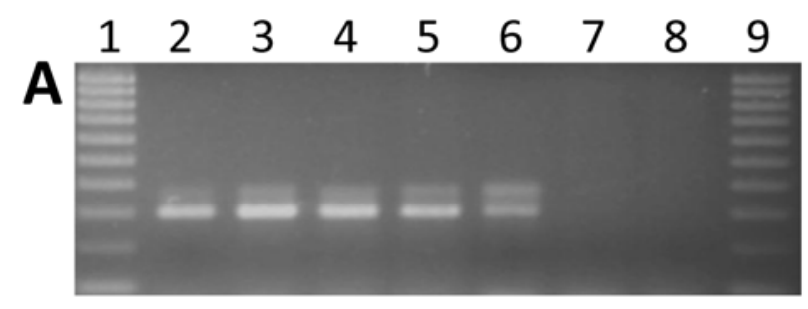

B
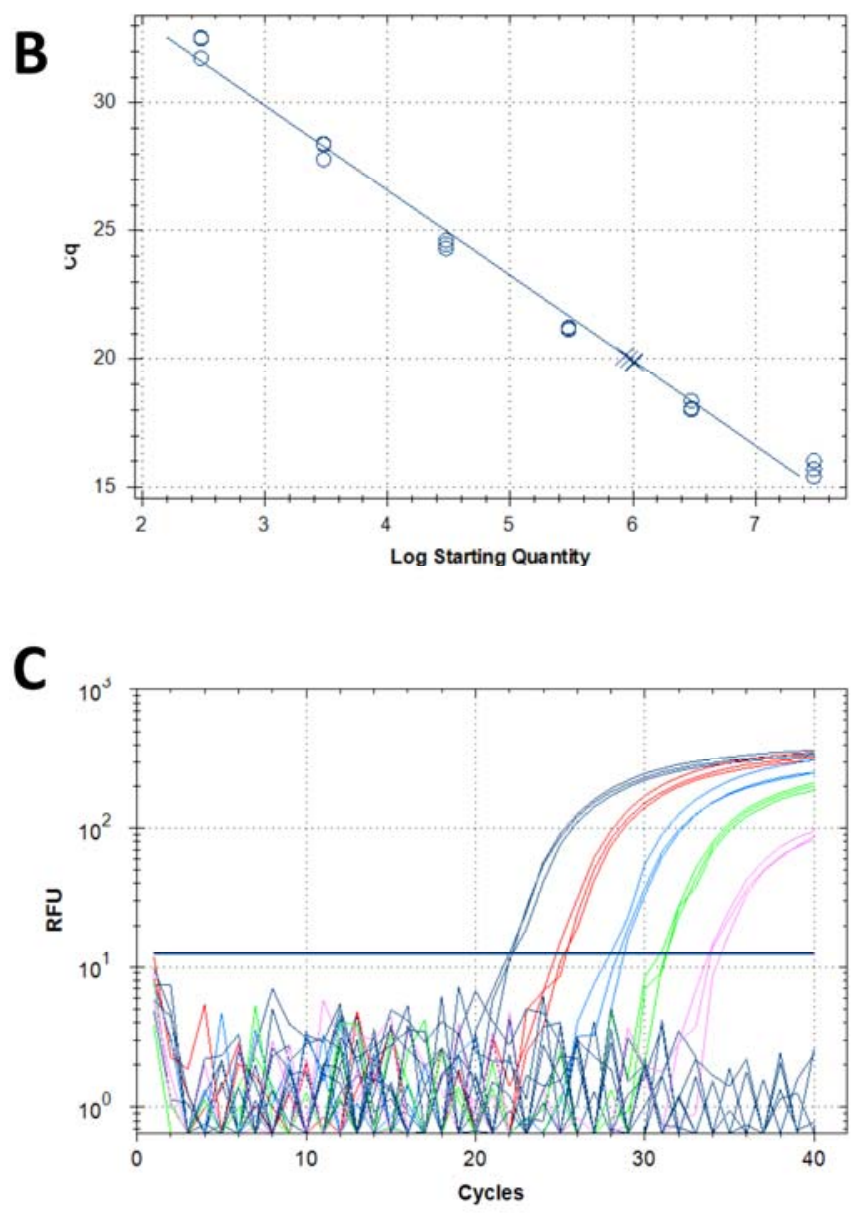

$302 b p$

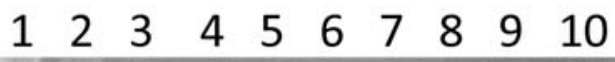

Fig. 2. Detection of Blackberry yellow vein associated virus (BYVaV) by end-point and quantitative polymerase chain reaction (PCR). A, Lanes 1 and 9, DNA ladder; lanes 2-6, blackberry samples exhibiting yellow vein disease symptoms and infected with BYVaV; lanes 7 and 8 , healthy nursery materials. B, Standard curve of TaqMan qPCR BYVaV2.867 assay. Efficiency $=100.2 \%$; coefficient correlation $=$ 0.991; slope $=3.317 ; y$-intercept $=39.842$. Circles represent the standards, and Xs represent virus-infected plant CDNA. C, Quantitative PCR BYVaV2.867 (top) and end-point PCR (bottom) (BYVaVF/BYVaVR primers) detection sensitivity comparison. cDNA samples were serially diluted eightfold, corresponding to a threecycle difference. Quantitative PCR (three replications) and PCR could detect BYVaV at dilutions of $1 / 4,096$ and $1 / 64$ respectively. Lanes $1-8$, BYVaV cDNA dilutions; lane 9, negative cDNA control; lane 10, water control. RFU = relative fluorescence unit. 
in the transmission tests with T. abutilonea and 7 of 27 plants used in transmission with $T$. vaporariorum over three experiments were found to be infected by the virus (Table 4). BYVaV infection was confirmed by RT-PCR and verified by amplicon sequencing.

\section{Discussion}

The presence of BYVaV in the majority of the plants showing BYVD symptoms (3) made further studies mandatory in order to develop management strategies for both the virus and the disease. This study focused on several aspects of virus epidemiology: detection, incidence, host range, and transmission.

Detection is an important aspect of virus disease management but can be challenging in the case of new viruses because of insufficient information on virus diversity. Two sets of detection primers $(11,12)$ have been traditionally used in $\mathrm{BYVaV}$ detection but there were several cases where isolates were detected by only one set of primers (data not shown). Both detection tests developed in this study are based on the newly acquired knowledge of the population structure of the virus (6) and can amplify all sequenced isolates, reducing the chance of false negatives. They can be of use in nurseries, especially on first-generation (G1) plants that serve as the starting material for commercial nurseries, which will, in turn, minimize virus movement through the propagation material (10) and decrease the presence of BYVD in the field, because one of the major components of the complexes would be eliminated from the system.

Determination of the geographical distribution of $\mathrm{BYVaV}$ in cultivated and wild blackberry provides the first evidence of the presence of the virus based on extensive sampling, and resulted in the first report of the virus in Illinois and West Virginia.

Criniviruses are not mechanically transmissible, eliminating the possibility of traditional mechanical inoculation on indicator plants. For this reason, 25 species found in areas of high BYVD incidence, commercial fields or the wild, were tested for BYVaV. BYVaV was not detected in any of the almost 500 plants assayed. Most criniviruses have limited host ranges (20) and it can be challenging to find a host among the myriad plant species present around blackberry. Wild blackberry (Rubus spp.) and multiflora rose ( $R$. multiflora) habitats overlap in the southeastern United States. Whiteflies feed on rose plants, and most members of the Crinivirus group 1 are known to infect rosaceous hosts. For this reason, we grafted BYVaV-infected blackberry onto $R$. multiflora and determined that $\mathrm{BYVaV}$ can replicate and move systemically. No symptoms were observed on the infected rose even in a conducive environment for symptom expression. This was not unexpected because the virus is asymptomatic in single infections on blackberry, and the interaction may be comparable in the two rosaceous hosts. Rose plants have the potential to be reservoir hosts for BYVaV because symptomless infections would likely go undetected. Consequently, transmission studies were attempted to determine whether whiteflies could transmit $\mathrm{BYVaV}$ from blackberry to rose. As with blackberry, rose is not a preferred host for whiteflies in the colonies used for transmission. The fact that rose was found to be an experimental host of the virus through grafting cannot be ignored. It is possible that some whitefly populations in the wild are better adapted to rose and may feed more efficiently.

Vector identification is a key factor of any virus disease management, and T. vaporariorum and T. abutilonea have been identified

Table 4. Transmission rates of Blackberry yellow vein associated virus to 'Natchez' blackberry seedlings ${ }^{\mathrm{a}}$

\begin{tabular}{lcc}
\hline Experiment & Trialeurodes abutilonea & T. vaporariorum \\
\hline Experiment 1 & $4 / 7$ & $3 / 9$ \\
Experiment 2 & $5 / 8$ & $1 / 8$ \\
Experiment 3 & $3 / 10$ & $3 / 10$ \\
Total & $12 / 25$ & $7 / 27$ \\
\hline
\end{tabular}

${ }^{\mathrm{a}}$ Whiteflies were given an 18- to 24-h acquisition access period on infected Natchez source plants. Whiteflies were vacuum collected and placed in clip cages, 50 whiteflies per clip cage. A separate clip cage was used for each plant. as BYVaV vectors. Because of climatic change, movement of plant material through commercial trade, and changes in agricultural practices, whitefly populations are proliferating in areas in which they were rarely present only a few years ago. This leads to the postulation that BYVaV has the potential to become a more significant threat in growing areas where either of these whitefly vector species is present. It is noteworthy that BYVaV has been detected in sentinel plants in sites where whiteflies are scarce (A. Khadgi, unpublished data), suggesting that BYVaV can move even when vectors are not abundant. Furthermore, in the initial experiments with a 48-h AAP + 48-h IAP, whiteflies did not survive well (data not presented). Reducing the AAP to 18 to $24 \mathrm{~h}$ on source plants resulted in much lower whitefly mortality during transmissions. The use of older blackberry plants did not work well for the "domesticated" whitefly population used in the study because of their relatively low preference and lack of adaptation to blackberry. Significant numbers of greenhouse whitefly feeding has been observed on mature blackberry in coastal California (W. M. Wintermantel, unpublished observations). Therefore, it is apparent that some wild populations are more adaptive to the wider range of host options available in nature than domesticated populations reared on specific host plants for several generations. Long-term culturing of laboratory populations likely results in poor feeding efficiency on desirable hosts that would have been effective feeding hosts in the wild.

This article provides data that can minimize losses because of BYVD. Management strategies can be developed to monitor and control Trialeurodes populations. Application of insecticides or implementation of any integrated pest management approaches during the whitefly population peak seasons will reduce virus spread. Because BYVD requires the presence of multiple viruses, elimination or reduction of the most important virus in the complexes by cleaning-up nursery stock could minimize losses and prolong productivity and longevity of plantings.

\section{Acknowledgments}

Research was funded by the United States Department of Agriculture under the Specialty Crops Research Initiative (SCRI), award number 2009-5118106022; National Clean Plant Network (NCPN), award number 10-8100-1572; and a grant from the North American Raspberry and Blackberry Association (NARBA). We thank S. Sabanadzovic and Z. Pesic-VanEsbroeck for providing some of the samples used in the study.

\section{Literature Cited}

1. Clark, J. R., and Finn, C. E. 2008. New trends in blackberry breeding. Acta Hortic. 777:41-48.

2. Clark, J. R., Stafne, E. T., Hall, H. K., and Finn, C. E. 2007. Pages 19-144 in: Blackberry Breeding and Genetics, Plant Breeding Reviews. John Wiley \& Sons, Inc., New York.

3. Martin, R. R., Tzanetakis, I. E., Gergerich, R. C., Fernandez, G., and Pesic, Z. 2004. Blackberry yellow vein associated virus: a new crinivirus found in blackberry. Acta Hortic. 656:137-142.

4. Martin, R., MacFarlane, S., Sabanadzovic, S., Quito, D. F., Poudel, B., and Tzanetakis, I. E. 2013. Viruses and virus diseases of Rubus. Plant Dis. 97:168-182.

5. Poudel, B. 2011. Epidemiological studies on Blackberry yellow vein associated virus and Blackberry chlorotic ringspot virus. MS thesis, University of Arkansas, Fayetteville.

6. Poudel, B., Sabanadzovic, S., Bujarski, J., and Tzanetakis, I. E., 2012 Population structure of Blackberry yellow vein associated virus, an emerging crinivirus. Virus Res. 169:272-275.

7. Sabanadzovic, S., and Abou Ghanem-Sabanadzovic, N. 2009. Identification and molecular characterization of a marafivirus in Rubus spp. Arch. Virol. 154:1729-1735

8. Sabanadzovic, S., Abou Ghanem-Sabanadzovic, N., and Tzanetakis, I. E. 2011. Blackberry virus E: an unusual flexivirus. Arch. Virol. 156:16651669.

9. Strik, B. B., Clark, J. R., Finn, C. E., and Banados, M. P. 2008. Worldwide production of blackberries. Acta Hortic. 777:209-217.

10. Susaimuthu, J., Gergerich, R.C., Bray, M. M., Clay, K. A., Clark, J. R., Tzanetakis, I. E., and Martin, R. R., 2007. Incidence and ecology of Blackberry yellow vein associated virus. Plant Dis. 91:809-813.

11. Susaimuthu, J., Tzanetakis, I. E., Gergerich, R. C., Kim, K. S., and Martin, R. R. 2008. Viral interactions lead to decline of blackberry plants. Plant Dis. 92:1288-1292.

12. Susaimuthu, J., Tzanetakis, I. E., Gergerich, R. C., and Martin, R. R. 2006. Yellow vein-affected blackberries and the presence of a novel Crinivirus. 
Plant Pathol. 55:607-613.

13. Susaimuthu, J., Tzanetakis, I. E., Gergerich, R. C., and Martin, R. R. 2008. A member of a new genus in the Potyviridae infects Rubus. Virus Res. 131:145-151.

14. Thompson, J. D., Higgins, D. G., and Gibson, T. J., 1994. CLUSTAL W: improving the sensitivity of progressive multiple sequence alignment through sequence weighting, position-specific gap penalties and weight matrix choice. Nucleic Acids Res. 22:4673-4680.

15. Tzanetakis, I. E., Guzmán-Baeny, T. L., VanEsbroeck, Z. P., Fernandez, G. E., and Martin, R.R., 2009. First report of Impatiens necrotic spot virus in blackberry in the Southeastern United States. Plant Dis. 93:432-432.

16. Tzanetakis, I. E., Postman, J. D., and Martin, R. R. 2007. Identification, detection and transmission of a new Vitivirus from Mentha. Arch. Virol. 152:2027-2033.

17. Tzanetakis, I. E., Susaimuthu, J., Gergerich, R. C., Bray, M., and Martin, R. R. 2008. Evidence of mixed virus infections causing severe symptoms and decline of blackberries. Acta Hortic. 777:385-390.

18. Tzanetakis, I. E., Susaimuthu, J., Gergerich, R. C., and Martin, R. R. 2006. Nucleotide sequence of Blackberry yellow vein associated virus, a novel member of the Closteroviridae. Virus Res. 116:196-200.

19. Tzanetakis, I. E., Wintermantel, W. M., Cortez, A. A., Barnes, J. E., Barrett, S. M., Bolda, M. P., and Martin, R. R. 2006. Epidemiology of Strawberry pallidosis associated virus and occurrence of pallidosis disease in North America. Plant Dis. 90:1343-1346.

20. Tzanetakis, I. E., Martin, R. R., and Wintermantel, W. M. 2013 Epidemiology of criniviruses, an emerging problem in world agriculture. Frontiers Microbiol. 4:119.

21. Wintermantel, W., Hladky, L., Gulati-Sakhuja, A., Li, R., Liu, H.-Y., an Tzanetakis, I. E. 2009. The complete nucleotide sequence and genome organization of Tomato infectious chlorosis virus: a distinct crinivirus most closely related to lettuce infectious yellows virus. Arch. Virol. 154:1335 1341 